\title{
Kartlegging av funksjon ved kronisk utmattelsessyndrom
}

\author{
Kronisk utmattelsessyndrom/myalgisk encefalopati fører til arbeidsmessig og sosialt funksjonstap. Instru- \\ menter som registrerer pasientens opplevde funksjon og helse og som måler endringene over tid, er en viktig \\ tilnærming i diagnostikk og oppfølging av disse pasientene.
}

Kronisk utmattelsessyndrom (CFS/ME) er en alvorlig, kompleks multisystemsykdom som ofte starter i de aktive årene for utdanning og jobb (alder 20-40 år) (1). Tilstanden kan være invalidiserende, og 35-69\% av pasientene er ute av arbeidsliv eller studier (2). Tidsperspektivet for fravær fra studier og arbeid er i liten grad undersøkt. I tillegg påvirker tilstanden den sosiale funksjonen (3). Disse pasientene trenger oppfølging over lang tid.

Arbeidsmiljøloven legger til grunn for oppfølging av sykmeldte at det utarbeides en plan for tilbakeføring til arbeid. Planen skal ta hensyn til helse- og funksjonsproblemer og graden av disse hos den enkelte pasient (4). Vi mener at kunnskapen om arbeidsrelatert funksjonshemning og hvilke tiltak som er effektive for å få pasienter med kronisk utmattelsessyndrom tilbake til jobb, er mangelfull. En oversiktsartikkel fra 2004 viser at i bare 37 av 3840 engelskspråklige artikler publisert 1988-2001 tar man for seg arbeidsstatus og mål for fysisk og kognitiv funksjonssvikt knyttet til uførhet hos pasienter med kronisk utmattelsessyndrom (5).

I 1996 etablerte vi ved Nevrologisk avdeling på Haukeland universitetssykehus en fatiguepoliklinikk for diagnostikk og funksjonsvurdering ved mistanke om kronisk utmattelsessyndrom. Vårt viktigste diagnoseverktøy har vært det kliniske intervjuet med sykehistorie og detaljert symptomog forløpsbeskrivelse. I tillegg har vi brukt tre spørreskjemaer med validerte psykometriske egenskaper for å måle utmattelse og funksjonshemning: Fatigue Severity Scale (FSS) (6), The Work and Social Adjustment Scale (WSAS) (7) og The 36item Short Form Health Survey (SF-36) (8). Disse skjemaene er hittil hovedsakelig brukt i kliniske studier, ikke i den daglige diagnostikken og oppfølgingen av pasienter.

\section{Kartlegging av funksjon}

FSS-skjemaet består av ni spørsmål med svarskår 1-7 der man skal beskrive hvordan utmattelsen påvirker de daglige funksjonene. Vi har benyttet den norske, validerte utgaven av dette skjemaet (tabell 1) (9). Gjennomsnittlig totalskår på 5 eller høyere beskrives som patologisk. Skjemaet kan skille utmattelsen ved kronisk utmattelsessyndrom fra tretthet hos friske kontrollpersoner, og både symptomer og funksjonshemning blir beskrevet.

WSAS-skjemaet vurderer i hvilken grad
Tabell 1 Skala for gradering av det å være sliten, uopplagt og ha mangel på overskudd (9). Gjengitt med tillatelse

Velg et tall fra 1 til 7 som angir i hvor stor grad du er enig med hvert enkelt utsagn, der 1 angir at du er helt uenig og 7 at du er helt enig (sett ring rundt ett tall for hvert utsagn).

\section{Helt uenig Helt enig}

1) Min motivasjon er lavere når jeg er sliten og uopplagt

1234567

2) Fysisk aktivitet gjør meg sliten og uopplagt

1234566

3) Jeg blir fort sliten og uopplagt

1234567

4) Det at jeg er sliten og uopplagt, virker inn på hvordan jeg fungerer fysisk

5) Det at jeg er sliten og uopplagt, skaper ofte vanskeligheter for meg

6) Det at jeg er sliten og uopplagt, hindrer meg i å opprettholde min fysiske funksjonsdyktighet over tid

1234567

7) Det at jeg er sliten og uopplagt, virker inn på evnen til å utføre visse oppgaver og plikter

123345667

Det at jeg er sliten og uopplagt, er ett av de tre symptomene som hemmer meg mest

234567

9) Det at jeg er sliten og uopplagt, virker inn på mitt arbeid, mitt familieliv eller min omgang med venner og kjente
1234567

1234567 sykdommen påvirker pasientens evne til å utføre daglige aktiviteter som jobb, husarbeid og fritidsaktiviteter og å opprettholde sosiale relasjoner (7). Hver variabel har skår fra 0 (intet problem) til 8 (meget alvorlig problem). Totalskåren er 0-40. Denne skalaen finnes i validert utgave på engelsk, men ikke på norsk. Til bruk i vår praksis har vi selv oversatt skjemaet til norsk. I en studie fra 2011 ble denne skalaen sammenliknet med en rekke andre selvrapporterte spørreskjema i to store pasientkohorter, og man konkluderte med at den gir et akseptabelt mål på uførhet både for forskning og i daglig klinisk praksis (10)

I SF-36 vurderes helserelatert livskvalitet og funksjon gjennom 36 spørsmål som er delt i underkategoriene fysisk aktivitet, sosial aktivitet, vitalitet/energi, smerte, mental og generell helse i tillegg til to funksjonskategorier: rollebegrensning for arbeid og daglige aktiviteter på grunn av henholdsvis fysisk helse eller emosjonelle problemer. Jo høyere skår, jo bedre funksjon og helse. Pasienter med kronisk utmattelsessyndrom har stor funksjonssvikt og SF-36profilen er distinkt; svært lav fysisk funksjon, lav sosial funksjon og markert redusert vitalitet/energi. Derimot er mental helse bare lett påvirket (11).

\section{Kliniske studier}

I tre kliniske studier har vi brukt disse skjemaene for å vise hvordan lavt energinivå påvirker alle aspekter av hverdagsfunksjonen til pasienter med kronisk utmattelse. I 2010 publiserte vi resultatene av en studie av 873 pasienter diagnostisert med kronisk utmattelsessyndrom (12). Disse pasientene var henvist fra hele landet til fatiguepoliklinikken i perioden 1996-2006. Gjennomsnittsalder ved diagnosetidspunktet var 33 år og sykdomsvarighet fem år. Pasientene anga betydelig utmattelse med en gjennomsnittlig totalskår på FSS-skalaen på 6,6 , mot 3 for friske kontrollpersoner. Til sammenlikning skårer multippel sklerose-pasienter uten arbeidskapasitet 5,3 (13).

I en nylig publisert studie undersøkte vi FSS- og WSAS-skår og arbeidsstatus hos 92 pasienter med kronisk utmattelsessyndrom utløst av mononukleose i tidsrommet 1996-2006 (14). WSAS- og FSS-skår korrelerte godt. Langtidsprognosen var god for en stor gruppe; 46 av 92 pasienter var ved undersøkelsestidspunktet i 2009 tilbake i del- eller fulltidsjobb, gjennomsnittlig 
11 år etter symptomstart. Gruppen som var tilbake i jobb hadde lav skår på utmattelse og ingen konsentrasjonsproblemer i 2009. Overgang til delvis uføretrygd (15 pasienter) eller full uføretrygd (39 pasienter) var assosiert med lang sykdomsvarighet, leddsmerter og depresjon, men ikke med utmattelsesskår.

I en tredje studie undersøkte vi langtids sykefravær og arbeidsuførhet for 96 pasienter med langvarig utmattelsestilstand etter vannbåren giardiainfeksjon høsten 2004 i Bergen (15). 58 av pasientene ble diagnostisert med kronisk utmattelsessyndrom. Symptombelastningen var stor: De fleste hadde smerter, konsentrasjonsproblemer og hukommelsessvikt. Pasientene rapporterte tilsvarende høye verdier for utmattelse som i den første studien, med en FSS-totalskår på 6,6. Svarprofilen ved SF-36 viste det typiske mønsteret for kronisk utmattelsessyndrom med sterkt redusert fysisk kapasitet, vitalitet og sosial funksjon. Emosjonell og mental funksjon var bare lett redusert. Tilsvarende mønster er observert i en norsk oppfølgingsstudie av pasienter med kronisk utmattelsessyndrom (16). Resultatene bekrefter funn fra andre studier som viser at tilstanden er invalidiserende og kan ha en større innvirkning på helserelatert livskvalitet enn andre alvorlige, kroniske tilstander, som f.eks. kreft (17).

\section{Konklusjon}

Kronisk utmattelsessyndrom medfører høy og særpreget sykdomsbelastning i form av nedsatt kapasitet og utholdenhet og problemer med å mestre de daglige aktiviteter. I tillegg opptrer alvorlige og uforutsigbare fysiske symptomer og kognitive problemer. Vi anbefaler å bruke spørreskjemaene FSS og WSAS både for diagnostikk og oppfølging av pasienter med kronisk utmattelsessyndrom. Med disse to skjemaene kan vi klinisk kartlegge energisvikt og funksjonstap, som utgjør hovedkriteriet for diagnosen. Vår erfaring er at spørreskjemaene er enkle å fylle ut for pasientene. Skjemaene er dessuten validert i flere studier av utmattelse ved en rekke nevrologiske og psykiatriske tilstander $(6,7)$. SF-36 er derimot et omfattende skjema som særlig brukes i kliniske studier og forskning og er lisensbelagt.
FSS- og WSAS-skår er grunnlagsdokumenter som kan følge pasienten og oppdateres gjennom sykdomsforløpet. Vår erfaring er at pasientene er positive til å kunne formidle påkjenningene det innebærer å leve med kronisk utmattelsessyndrom. Skjemaene beskriver også funksjonssvikten og bidrar til å ivareta hans/hennes behov og mål i rehabiliteringsprosessen. Benytter man ikke slike spørreskjemaer, går man glipp av forståelsen av hvor store konsekvenser denne formen for utmattelse har for den daglige funksjon. Da mister man det viktigste grunnlaget for tverrfaglige tiltak i pasientoppfølgingen.

\section{Harald Nyland}

harald.nyland@helse-bergen.no

\section{Halvor Næss}

Morten Nyland

Harald Nyland (f. 1942) er dr.med., spesialist i nevrologi og professor emeritus. Han var rådgiver for Rikstrygdeverket da retningslinjene for diagnostikk og trygderettigheter til pasienter med kronisk/postviralt utmattelsessyndrom ble publisert.

Forfatter har fylt ut ICMJE-skjemaet og oppgir ingen interessekonflikter.

Halvor Næss (f. 1957) er spesialist i nevrologi og indremedisin og overlege på Nevrologisk avdeling. Haukeland universitetssykehus og professor II ved Universitetet i Bergen.

Forfatter har fylt ut ICMJE-skjemaet og oppgir ingen interessekonflikter.

Morten Nyland (f. 1974) er sosiolog og har som forskningsassistent hatt ansvaret for et prosjekt for arbeidsrettet rehabilitering for pasienter med kronisk utmattelsessyndrom ved Nevrologisk avdeling, Haukeland universitetssykehus. Han har kvalitetssikret instrumenter for kartlegging av helse og funksjon i ICF-klassifikasjonen.

Forfatter har fylt ut ICMJE-skjemaet og oppgir ingen interessekonflikter.

\section{Litteratur}

1. Afari N, Buchwald D. Chronic fatigue syndrome: a review. Am J Psychiatry 2003; 160: 221-36.

2. Taylor RR, Kielhofner GW. Work-related impairment and employment-focused rehabilitation options for individuals with chronic fatigue syndrome: A review. J Ment Health 2005; 14: 253-67.

3. Schweitzer R, Kelly B, Foran A et al. Quality of life in chronic fatigue syndrome. Soc Sci Med 1995; 41 1367-72.

4. Rikstrygdeverket. Retten til rehabiliteringspenger og uførepensjon for personer med kronisk/postviralt utmattelsessyndrom. Kap. 10, nr. 2. Oslo: Rikstrygdeverket, 1999

5. Ross SD, Estok RP, Frame D et al. Disability and chronic fatigue syndrome: a focus on function. Arch Intern Med 2004; 164: 1098-107.

6. Krupp LB, LaRocca NG, Muir-Nash J et al. The fatigue severity scale. Application to patients with multiple sclerosis and systemic lupus erythematosus. Arch Neurol 1989; 46: 1121-3

7. Mundt JC, Marks IM, Shear MK et al. The Work and Social Adjustment Scale: a simple measure of impairment in functioning. Br J Psychiatry 2002; 180: 461-4.

8. Ware JE Jr, Sherbourne CD. The MOS 36-item short-form health survey (SF-36). I. Conceptual framework and item selection. Med Care 1992; 30: 473-83

9. Lerdal A, Wahl A, Rustøen T et al. Fatigue in the general population: a translation and test of the psychometric properties of the Norwegian version of the fatigue severity scale. Scand J Public Health 2005; 33: 123-30

10. Cella M, Sharpe M, Chalder T. Measuring disability in patients with chronic fatigue syndrome: reliability and validity of the Work and Social Adjustment Scale. J Psychosom Res 2011: 71: 124-8.

11. Hardt J, Buchwald D, Wilks D et al. Health-related quality of life in patients with chronic fatigue syndrome: an international study. J Psychosom Res 2001: 51: 431-4.

12. Naess H, Sundal E, Myhr KM et al. Postinfectious and chronic fatigue syndromes: clinical experience from a tertiary-referral centre in Norway. In Vivo 2010; 24: 185-8.

13. Flensner G, Landtblom A-M, Söderhamn 0 et al. Work capacity and health-related quality of life among individuals with multiple sclerosis reduced by fatigue: a cross-sectional study. BMC Public Health 2013; 13: 224.

14. Nyland M, Naess H, Birkeland JS et al. Longitudinal follow-up of employment status in patients with chronic fatigue syndrome after mononucleosis. BMJ Open 2014; 4: e005798.

15. Naess H, Nyland M, Hausken T et al. Chronic fatigue syndrome after Giardia enteritis: clinical characteristics, disability and long-term sickness absence. BMC Gastroenterol 2012; 12: 13.

16. Stubhaug B. Chronic fatigue syndrome. Health and impairment, treatment and prognosis. Thesis. University of Bergen, 2008

17. Nacul LC, Lacerda EM, Campion P et al. The functional status and well being of people with myalgic encephalomyelitis/chronic fatigue syndrome and their carers. BMC Public Health 2011; 11: 402.

Mottatt 5.5. 2015, første revisjon innsendt 30.6. 2015, godkjent 19.8. 2015. Redaktør: Lise Mørkved Helsingen.

Publisert først på nett. 